\title{
Plautus and Ionesco - A Contrastive Perspective
}

Monica Adriana IONESCU

University of Bucharest

This paper is a study of applied poetics in which I study the problems which are put in most of dramas. I am going to explore the differences between Plautus and Ionesco and, at the same time, to analyse the link, as the texts reveal it.

Democracy means the power of people in etymological sense. Democracy means also freedom (of expression).

The drama of Plautus flourished in the period of the Roman Republic, his creation showing marginalized people (homines liberi et servi).

In the fifties, E. Ionescu re-starts using another language and another culture, after leaving (in fact escapes) from Romania, under the pretext of the studies, for political reasons, choosing freedom (France: a democratic country). Ionesco experienced a tragedy, when he discovered that gradually his colleagues become adherents or sympathizers of The Iron Guard of the legionary movement, the play The Rhinoceros (1958) having the stemming from this experience. He never declared openly his Jewish identity, shutting down (concealing, stifling) this truth, having three identities: a Romanian refused identity, a French desirable identity, a Jewish repressed identity.

The drama of Plautus circumscribes classic(al) poetics which is characterized by features such as: harmony, unity, symmetry, rationality, verisimilitude ( mimesis within the limits of the verisimilar and of the necessary). On the other hand, the drama of Ionesco circumscribes postmodernist poetics of the indetermination (indeterminacy, fragmentation, decanonization, self-less-ness, depth-less-ness, the 
Plautus and Ionesco - A Contrastive Perspective

unpresentable, unrepresentable, irony, hybridization, carnivalization, performance, participation, constructionism, immanence).

Two dramatic systems which are placed at two opposite poles: one which is subordinated to the logic of Aristoteles, as formal principle, other, to the tripolar ideal logic of the impossible and to the aestetics of the hazard (which implies the fragmentation, the contradiction, the juxtaposition).

My research will emphasize the topics, the characters (from the point of view of the main title of the conference: Drama and Democracy), but also the writing of two authors, this study being an exegesis of the dramatic text. (It refers to the written texts with a view to tuning the drama into plays and not the perfomed plays proper.)

The motifs of the 21 comedies which form Corpus Plautinum are the following:

a) the phenomenon of moral disintegration of family life;

b) the emergence of the women mongers in the Roman society- leno;

c) the Greek way of life (partying represents the motif of plays like Mostellaria, Persa);

d) the emergence of the courtesans in the Roman society;

e) the sacrifice of the slaves for their masters;

f) the arrogance and illiteracy of the mercenary warriors, boaster, stupid and immoral;

g) religious issues with a political under-layer;

h) the Roman woman of very high morals;

The researchers of the Plautine work have established that in approximately 13 of these plays, the plot is reduced to the following pattern: a young man is in love with a courtesan (free or slave at origin) and he undertakes all actions in order to get the object of his love, hence the development of all kinds of adventures. Although the majority of Plautus's plays have a similar plot, their actions are extremely varied.

Other plays have a different kind of plot. In Aulularia the plot develops on two levels: the adventures of a pot full of money and those due to the inner torments of a miser. In Menaechmi the events take place due to the 


\section{Monica Adriana IONESCU}

resemblance of the two brothers. In Amphitryon, the adventures are caused by the resemblance between Sosia and Mercury, between Amphitryon and Jupiter; in Trinummus, events that lead to the finding of a lost treasure.

The original situation of the characters evolves according to a certain determinism which implies the logical or verisimilar progression, based on the principle of causality. The Plautine theatre circumscribes to the GreekLatin aesthetics of harmony, composition principles (unity, symmetry), and the continuous and logical progression of the dialogue corresponds to a universe that complies with rational laws.

The characters are the classic general human types, the world of the slaves being very well represented and extremely varied (domestic slaves: pedagogues, flautists, lyre players, cooks and so on) in Plautus's dramas.

qui advorsum stimulos, lamminas, crucesque compedesque, nervos, catenas, carceres, numellas, pedicas, boias indoctoresque acerrumos gnarosque nostri tergi, [qui saepe ante in nostras scapulas cicatrices indiderunt] eae nunc legiones, copiae exercitusque eorum vi pugnando periuriis nostris fugae potiti.

$$
\text { (Asin., 548-555) }
$$

They fight in order to acquire freedom, since slavery is very tough under the rule of the rich.

opulento homini hoc servitus dura est,

hoc magis miser est divitis servos: (Amph.165)

In Plautus's comedies, the homines liberi are also represented, the misery of their life being atrocious.

hisce hami atque haec harundines sunt nobis quaestu et cultu.

*** ex urbe ad mare huc prodimus pabulatum:

pro exercitu gymnastico et palaestrico hoc habemus;

echinos, lopadas, ostreas, balanos captamus, conchas, marinam urticam, musculos, plagusias striatas;

post id piscatum hamatilem et saxatilem aggredimur. cibum captamus e mari: si eventus non evenit

neque quicquam captumst piscium, salsi lautique pure 


\section{Plautus and Ionesco - A Contrastive Perspective}

domum redimus clanculum, dormimus incenati.

atque ut nunc valide fluctuat mare, nulla nobis spes est:

nisi quid conclarum capsimus, incenati sumus profecto.

(Rudens, 294-304)

In Aulularia, in the case of the character Euclio, avarice is associated with terrible poverty.

STAPH. Quippini?

ego intus servem? an ne quis aedes auferat?

nam hic apud nos nihil est aliud quaesti furibus,

ita inaniis sunt oppletae atque araneis.(Aulularia, 81-84)

nam si ignis vivet, tu extinguere extempulo.

tum aquam aufugisse dicito, si quis petet. .(Aulularia, 93-94)

Women appear mostly as courtesans. The Roman society is an androcratic one, the life of married women being confined by the rights of the men. The courtesan type is a very interesting one. She is greedy, unscrupulous, an expert in the art of seduction, like Phronesium in Truculentus. In Bacchides the courtesans are coquettish, delicate, insidious, Plautus illustrating this plague of the Roman society. Women are sold or they sell themselves in order not to die of hunger.

et ego et tua mater, ambae

meretrices fuimus: illa te, ego hanc mihi educavi

ex patribus conventiciis. neque ego hanc superbiai $\quad 40$

causa pepuli ad meretricium quaestum, nisi ut ne esurirem.

(Cistellaria, 38-41)

The most grotesque type of character in Plautus's comedies is leno, the women monger. They are as well unscrupulous and have no shame, just as Ballio in Pseudolus.

A category of the free people is represented by the parasites that form the clientele of the rich, and live a miserable existence.

quasi mures semper edimus alienum cibum; ubi res prolatae sunt, quom rus homines eunt, simul prolatae res sunt nostris dentibus. (Captivi, 77-79) 


\section{Monica Adriana IONESCU}

The parasites Saturio and Curculio lead the action (plot) of the plays Persa and Curculio.

The type of the braggart and stupid solder, immoral, womanizer, boaster can be found in Miles Gloriosus, in Truculentus, and so on.

The young ones, sons of the rich, have two vices: lack of occupation (laziness) and love for the courtesans.

The majority of Plautus's elderly characters are estate owners, have mansions, bailiffs (grangers) and, of course, slaves. They (the elderly) entertain together with their sons in the houses of the courtesans, like in Bacchides or fight against their children (sons) for the slave they are both in love with, like in Casina or in Mercator.

The Plautine plays are musical comedies. They were written not to be read, but to be played (sang or spoken).

\section{EUGEN IONESCU AND THE AVANT-GARDE THEATRE}

Eugen Ionescu uses the word absurd in order to describe what he cannot understand, what he perceives as impenetrable, incomprehensive, more types of "absurd" things or facts being valid in his vision. ${ }^{1}$

Eugen Ionescu prefers the term unusual, strange to the term absurd.

Et on appelle quelquefois l'absurde ce qui n'est que la denunciation du caractère dérisoire d'un langage vide de sa substance, sterile, fait de clichés et de slogans. (Ionesco, Notes et contre-notes: $83-84)^{2}$

Eugen Ionescu is the theoretician and the creator of the avant-garde theatre.

The avant-garde belongs to modernism but it delineates and differentiates itself from it by its radicalism and its anti-aestheticism. What the avant-garde and the modernism have in common is the search for innovation by all means, of innovation that needs to be quickly replaced by another innovation.

Eugen Ionescu prefers to define the avant-garde in terms of fracture and opposition, the avant-garde person being the opponent of a current system. 


\section{Plautus and Ionesco - A Contrastive Perspective}

An avant-garde author needs to express a fracture, an innovation, an opposition.

In the article "Speech on Avant-Garde", Eugen Ionescu points out that the theatre is the field where one has dared the least. The avant-garde has come to a halt in theatre which is therefore the most delayed of all fields. The innovative movement in theatre seems to have stopped in 1930. $(3)^{3}$

In Eugen Ionescu's vision, the approach of an avant-garde author is a true return to the origins of the theatre, a return to an inner theatrical paradigm. C'est en soi-même que l'on retrouve les figures et les schemes permanents, profound, de la théâtralité. (Ionesco, Notes et contre-notes: 86

He believes that the theatre requires experimenting places, laboratory rooms, sheltered from the shallowness of the general public. He is the advocate of the experimental, laboratory, avant-garde theatre, for the that kind of theatre that is alive and free, $(5)^{4}$ a theatrical work has to be a true authentic intuition. $(6)^{5}$

From the perspective of Pierre Bourdieu, a literature sociologist, the literary field is the space of battle between those who mark a date (bringing into existence a new position in the field) and who fight in order to further exist (to become "classics"), and those who, in their turn, cannot mark a date without sending in the past the first ones whose interest is to eternalize the present actuality.

In the conflicts which, within their own genre, bring face to face the established avant-garde and the new avant-garde", the latter is forced to question the very basis of the genre itself, claiming itself from the return to the origins, to the purity of its sources; hence, it ensures that the history of the poetry, of the novel and of the theatre tends to present itself as a purification process through which each of these genres is more and more reduced to its purest quintessence, through a ceaseless critical recurrence on itself, on its own principles, suppositions. (Bourdieu 1999: 53 - 54)

The denial of tradition and of established values is a strategy which Eugen Ionescu resorts to, due to the constraints of the structure of the 


\section{Monica Adriana IONESCU}

literary field, a strategy which allows him to construct his own position in the perimeter of the same field. For instance, in his volume of essays No (1934) Eugen Ionescu abolishes the poetry of Arghezi, Barbu, the fiction of Camil Petrescu, the prose of Eliade. Eugen Ionescu has made his debut in Romania with his volume Elegies for Little Beings (1931) but this has not given him the possibility to secure a position within the literary field. The writers denied by Ionescu in his volume $N o$, were successful with the books they had published not long before 1934 when the volume No was published. Tudor Arghezi had published in 1927 his poetry volume Proper Words, followed within just a few years by Mildew Flowers. Ion Barbu had published in 1930 his poetry volume Secondary Game. Camil Petrescu had published in 1930 his novel The Last Night of Love, the First Night of War (novel which was a great success at that time) and in 1933 he published The Bed of Procustres. In 1933 as well, Mircea Eliade published his novel Maitreyi.

What happens in the 1950s when Eugen Ionescu makes his debut again in a new language and in a new culture? He will reject the theatre that expresses. Although he despises the popular theatre he nevertheless admits its existence. However, what is Eugen Ionescu's attitude towards dramatists just as himself? In his vision, they belong to a caste of the aristocracy of the spirit, Eugen Ionescu being impregnated by profound admiration for passionate writers such as: Jean Genet, Beckett, Vauthier, Pichette, Adamov, Schehadé, Audiberti, Weingarten, Georges Neveux. Just like for Victor Hugo the romanticism was nothing more than the liberalism in literature $^{\mathbf{3}}$, for Eugen Ionescu the avant-garde represents freedom.

\section{THE "ILLOGICAL" LOGIC OF THE IONESCIAN DIALOGUE}

In order to penetrate into the specificity of the Ionescian theatre, I created the chapter named "The Illogical Logic of the Ionescian Dialogue", which opens with a metatext excerpt from the play Victims of Duty, reflecting Eugen Ionescu's principles regarding the theatre. In this excerpt, Ionescu 


\section{Plautus and Ionesco - A Contrastive Perspective}

refers to one of Ştefan Lupaşcu's books - Logic and Contradiction - , proposing an interpretation pattern of his dramaturgy the ideal tripolar logic of the impossible.

I shall begin this chapter with a passage from the "Victims of Duty", a passage which reflects Eugen Ionescu's outlook on theatre. In this text Ionescu proposes a reading (interpretation) pattern of his drama, inviting the lecturer to read Lupaşcu's "excellent" book "Logic and Contradiction."

Nicolas. - J'ai beaucoup réfléchi sur la possibilité d'un renouvellement du théâtre. Comment peut-il y avoir du nouveau au theatre ? Qu'en pensez-vous, Monsieur l'Inspecteur principal ? (...) M'inspirant d'une autre logique et d'une autre psychologie, j'apporterais de la contradiction dans la non- contradiction, de la non- contradiction dans ce que le sens commun juge contradictoire...(...) Vous auriez intérêt d'ailleurs à lire Logique et Contradiction, l'excellent livre de Lupasco...(Ionesco, Victimes du Devoir. Tome I: 218-220)

In "Logic and Contradiction" Lupaşcu talks about the "tridialectic of the possible", about the "ideal tripolar logic of the impossible". He proves that "the logical experience - experience, in short - explains a logic whose bivalence implies a polar trivalence and a possible polyvalence. Indeed, logic does not possess anymore a true and a false about which one does not know exactly whether it stands for negation or for contradiction, or a true and a false and no true and no false, with all the possible finite or infinite values in these three values, but, as we already saw, two reversed and contradicting truths from each other: a true and a non-contradiction of affirmation and identity and a true and a non-contradiction of negation and non-identity, but also a false representing the third value which is not the negation of the true, but the contradictory coexistence in the same degree of the two truths. Therefore, all three represent ideal and impossible poles towards which the two relative possible truths converge (or asymptotically transcendent) and the relative possible false (or asymptotically immanent). Therefore the logic proves itself to be tripolar and the polyvalence is possible among these three ideal polar values. But opposed to the values of 


\section{Monica Adriana IONESCU}

the classic polyvalent logic, here none of the values is autonomous, solitary and as if suspended in vacuum, but each represents a duality, a symbiosis of the two contradictory truths of which one is, more or less, only dominating and virtualizing the other one by its relative updating and is therefore, more or less, moving away or approaching the false, which is a kind of irreducible contradiction that can be minimized at any time without the possibility of ever making it entirely disappear. (...) Any logical value thus proves to be statistic and probable. (...) In short, the only way is that of the possible." (Lupasco 1982: 161-171)

I shall emphasize that Lupaşcu proposes a new dynamical logic of the contradictory, to which the Ionescian theatre is circumscribed, and he does not just merely operate an amendment to the classical polyvalent logic.

The theatre invented by Eugen Ionescu circumscribes in another kind of logic, different than the formal one.

In Eugen Ionescu's drama we encounter the deconstruction of the former categories: character, plot, action, dialogue.

Deconstruction is inflicted by Jacques Derrida's theories and represents the attempt penser la généalogie structure de ses concepts de la manière la plus fidèle, to determiner ce que cette histoire a pu dissimuler ou interdire. (Derrida, Positions: 15) ${ }^{4}$

Ambiguity does not originate in an explicit intention of pretence and deformation and is not provoked by a particular Dasein. Ambiguity relates to the existential fact of-being-together-with-others.

In the Ionescian's playwrights the chatter is ubiquitous.

With "The Bald Soprano" we enter the realm of the impersonal Se (it). The chatter is represented by an accumulation of clichés, of verbal automatisms.

Madame Smith: Tiens, il est neuf heures. Nous avons mangé de la soupe, du poisson, des pommes de terre au lard, de la salade anglaise. Les enfants ont bu de l'eau anglaise. Nous avons bien mangé, ce soir. (Ionesco, La Cantatrice chauve, Tome I: 19) 


\section{Plautus and Ionesco - A Contrastive Perspective}

The author denounces the "sclerotic", "calcified" thinking.

Les Smith, les Martin ne savent plus parler parce qu'ils ne savant plus penser, ils ne savent plus penser parce qu'ils ne savant plus s'émouvoir, n'ont plus de passions, ils ne savent plus être, ils peuvent devenir n'importe qui, n'importe quoi, car, n'étant pas, ils ne sont que les autres, le monde de l'impersonnel, ils sont interchangeables. (Ionesco, Notes et contre-notes: 253)

The dialogue between Mr. And Mrs. Martin is impregnated by a detached, rushed curiosity which has nothing in common with the amazed contemplation of existence (of the world).

M. Martin: Mon Dieu, comme c'est curieux ! Moi aussi je suis originaire de la ville de Manchester, Madame!

Madame Martin: Comme c'est curieux ! (...)

Madame Martin: Comme c'est curieux ! quelle bizarre coïncidence ! Moi aussi, Monsieur, j'ai quitté la ville de Manchester, il y a cinq semains, environ.(Ionesco, La Cantatrice chauve, Tome I: 27)

The progression of the dialogue, lacking semantic and illogical continuity, is a series of clichéd proverbs, non-sense and puns.

M. Martin: Celui qui vend aujoud'hui un bœuf, demain aura un œuf. (...)

J'aime mieux un oiseau dans un champ qu'une chaussette dans une brouette. (...)

Je te donnerai les pantoufles de ma belle-mère si tu me donnes le cercueil de ton mari. (...) On ne fait pas briller ses lunettes avec du cirage noir.(...) Quelle cascade de cacades, quelle cascade de cacades (...)(Ionesco, La Cantatrice chauve, Tome I: 51-54)

Slowly, the language becomes disarticulated and the progression (of the dialogue) which does not respect the principle of causality, becomes an alphabetic concatenation.

M. Smith: A, e, i, o, u, a, e, i, o, u, a, e, I, o, u,i !

Madame Martin: B, c, d, f, g, l, m, n, p, r, s, t, v, w, x, z !

(Ionesco, La Cantatrice chauve, Tome I: 55) 


\section{Monica Adriana IONESCU}

The play "Girl for Marriage" is also placed under the sway of chatter.(15) $)^{13}$

Le Monsieur - De mon temps, les enfants étaient beaucoup plus obeissants, plus attachés à leurs parents dont ils comprenaient les sacrifices, les soucis, les difficultés matérielles... (...) Que voulezvous? Les enfants sont durs à élever par les temps qui courent !

(Ionesco, La Jeune Fille a Marier, Tome II: 249)

In "Courtesy?" the progression of the dialogue is ensured by phonetic concatenation. (16)

adénitemment, arthritiquement, astéroïdemment, astrolabiquement, atrabilairement, balalaïkemment, baobabamment, basculamment, bissextilement, cacologiquement, , callipygeusement, caniculeusement ... castapianeusement...

(Ionesco, Les Salutations, Tome III: 290)

In the drama "The Lesson" the progression of the dialogue is similar to mathematical exercises.

Le Professeur: Poussons plus loin: combien font deux et un ?

L'élève: Trois.

Le Professeur: Trois et un ?

L'élève: Quatre.

Le Professeur: : Quatre et un ?

L'élève: Cinq. (Ionesco, La Leçon: 37)

In Heidegger's view, the language includes both the listening (das Hören) and the silence (das Schweigen), the existential basis of language being (Rede). The act of speech is accompanied by the act of listening.

But the characters marked by autism and hallucinations in Eugen Ionescu's drama "The Chairs", do not listen to one another. The dialogue slowly organizes itself from answers which contradict one another.

La Vieille, au Photograveur. - Nous avons eu un fils... il vit bien sûr...il s'en est allé...il a abandonné ses parents...(...-

Le Vieux. - Helas, non...non...nous n'avons pas eu d'enfant...(...)

Le Vieux. - J'ai laissé ma mere mourir toute seule dans un fosse. (...)

La Vieille. - Lui qui aimait tellement ses parents. Il ne les a pas quittés un instant. (Ionesco, Les Chaises, Tome I: 148-149) 
Plautus and Ionesco - A Contrastive Perspective

"What cannot be spoken about must be silented" says Ludwig Wittgenstein at the end of the Tractatus Logico-Philosophicus. (Wittgenstein 1991: 123)

For Heidegger the authentic form of speaking is silence. ${ }^{\mathbf{1 8}}$

With Eugen Ionescu silence is frequent and is marked either by ellipsis, either by break.

In Eugen Ionescu's vision there is an inferior silence and a radiant silence. Au silence de lumière s'oppose un silence de boue.

(Bonnefoy 1966: 160)

The Ionescian dramas are "open" creations. ${ }^{\mathbf{2 0}}$ They are impregnated by ambiguity, the "openness" being a conscious principle with Eugen Ionescu. The "openness" is inflicted by indeterminacy and polysemy. In his drama "Jacques or Obedience" the dialogue reaches the absolute unintelligibility. A single significant, "cat", acquires an infinity of meanings. (19) ${ }^{\mathbf{2 1}}$

Roberte II - Dans la cave de mon château, tout est chat...

Jacques: - Oh, mon chat...(...)

Roberte II - Pour y designer les choses, un seul mot: chat. Les chat s'appellent chat, les aliments: chat, les insects:chat, les chaises: chat, toi:chat, moi:chat, le toit: chat (...) Chat, chat, chat, chat. (Ionesco, Jacques ou la soumission, Tome I: 121-122)

Eugen Ionescu rejects the Aristotelian logic as a formal principle. The Ionescian dramas sometimes follow the logic of the dream. "The illogical" originates in the very structure of the plays themselves. In "Hunger and Thirst" the daytime experience, hallucination, dream and day-dreaming are intertwined.

(Ionesco, La Soif et la faim, Tome IV: 78-103)

The drama "The Pedestrian of the Air" originates in a dream of levitation and is constructed as a succession of dream images. (20) ${ }^{\mathbf{2 3}}$

Bérenger: En effet, bien sûr, on ne voit rien. C'est la preuve qu'il faut aller en Irlande por les voir dans les glaces, ces paysages indescriptibles. (...) Peut-être pourrait-on avoir une vague idée de ce 


\section{Monica Adriana IONESCU}

monde quand on voit les tours d'un château se reflétant dans l'eau, une mouche la tête en bas au plafond, une écriture de droite à gauche et de bas en haut, un anagramme (celui-ci peut être représenté par un panneau avec des lettres majuscule qui s'enchevêtrent), un jongleur, un acrobate ou les rayons du soleil qui se réfractent, se brisent, se désintègrent en une poussière de couleurs après avoir traverse un prisme de crystal, pour se reconstituer, tu vois, sur ce mur, sur cet écran, sur tou visage, comme une lumière éclatante, unie ... et à l'envers... Heureusement que le centre de notre univers ne heurte pas celui de l'anti-monde... (Ionesco, Le pieton de l'air, Tome III: 147150)

The moments of day-dreaming, dreaming and hallucinations are juxtaposed. The Ionescian dialogue is circumscribed to an aesthetic of the hazard which implies fragmentation, contradiction and juxtaposition.

In Ionescu's view, the crisis undergone by the theatre is a crisis of expression renewal. (Bonnefoy 1966: 182) Eugen Ionescu does not believe in incommunicability. $(21)^{\mathbf{2 5}}$

Il ne reste à dire que la vérité, il ne reste à dire que l'indicible. Cela est impossible. Mais le non-communicable de ceux qui parlent de la crise du langage et de l'incommunicable est parfaitement communicable. (Ionesco, Journal en miette: 106)

The vision of the language is a vision of the world says Hans Georg Gadamer in "Truth and Method". (Gadamer 1976: 294) Due to Eugen Ionescu a "revolution" of the theatre is generated. He creates a new writing (a new type of writing), a new language (theatrical).

\section{DEATH IN EUGEN IONESCU'S WORK}

The fundamental obsession that has dominated Eugen Ionescu's life was the obsession of death.

J'ai toujours été obsédé par la mort. Depuis l'âge de quatre ans, depuis que j'ai su que j'allais mourir, l'angoisse ne m'a plus quitté. C'est comme si j'avais compris tout d'un coup qu'il n'y avait rien à faire pour échapper et qu'il n'y avait plus rien à faire dans la vie. As well, he has always had the feeling of an impossibility of communication, of an encirclement. 
Plautus and Ionesco - A Contrastive Perspective

J'écris pour lutter contre cet encirclement; j'écris aussi pour crier ma peur de mourir, mon humiliation de mourir, Ce n'est pas absurde de vivre pour mourir (Ionesco, Notes et contre-notes: 309)

From the point of view of Heidegger, death as supreme possibility is not the kind of possibility that the Dasein aims to acchieve. It is neither in a hurry, nor interested to push this possibility towards its achievement. No Dasein is concerned about causing its own death (decease). The state of being into death does not mean waiting in the neighbourhood of death, does not mean the uninterrupted thinking of death. Even though it does not take away its character as a possibility, this rumination weakens, dilutes its possibility. Death as a possibility must be understood without its attenuation as a possibility.

Im Sein zum Tode dagegen, wenn anders es die charakterisierte Möglichkeit als solche verstehend $\mathrm{zu}$ erschließen hat, mu $\beta$ die Möglichkeit ungeschwächt als Möglichkeit verstanden, als Möglichkeit ausgebildet und im Verhalten zu ihr als Möglichkeit ausgehalten warden. (Heidegger 1967: 261)

Another way of diluting the possibility of death is relating to the possibility of death in the form of waiting - das Erwarten.

Waiting is not a realisation of the authenticity of my relating to death. In waiting, we detach ourselves from the possible and we move towards the real.

The authentic relating to the state of being into death takes place when we consider death as anticipation, as a forerunning into the possibility Vorlaufen in die Möglichkeit. (25) ${ }^{19}$

Das Sein zum Tode als Vorlaufen in die Möglichkeit ermöglicht allererst diese Möglichkeit und macht sie als solche frei. (Heidegger 1967: 262)

This way, death as possibility is understood as possibility of the impossibility of existence, in general. It refers to the possibility of understanding the cessation of existence in this forerunning into the possible. 


\section{Monica Adriana IONESCU}

This possibility of the impossibility of existence stays in the area of the possible without being pushed towards realisation.

The Dasein opens to the absolute possibility. Authentic existence implies a forward slip, a forerunning into death as an impossibility of existence.

The Dasein escapes from the dominance of the Das Man. It becomes the most personal possibility. It understands its existence starting from the possibility of its own nonexistence. This forerunning towards its own self isolates the Dasein. Any contact with the others ceases. Death appears now as an absolute possibility. The Dasein assumes itself, starting from its own self.

Death must be seen as a possibility of our own existence. We do not consider real death. Death as extreme possibility of existence has to be removed from the field of updating in order to be contemplated authentically.

There is a difference between the passive expectation and the anticipation as a conscious forerunning towards the encounter with the possibility of nonexistence, possibility which is placed under the sign of the Vorlaufen. Death does not find its meaning from its interpretation as an event. What is existent is valued from the perspective of its capacity of not being anymore (of being able not to exist anymore).

The authentic vision of death is not fatalistic, but of a demanding and brave consciousness which derives from the consciousness of our own finitude.

The play "Exit the King" (1962) is a poem of death, the characters of the play being symbolic. The king Bérenger $I$ is the symbol of the man facing death, queen Marguerite, the king's first wife is the symbol of death, queen Marie, the king's second wife symbolizes life. The other characters: the Doctor, Juliette and the Guard represent the symbol of society, they embody the Heideggerian existentialism, mit-Sein - the fact of being together with others.

From the very beginning, a feeling of bizarreness is inflicted into the play, an unshelterness, represented by the crevice in the wall which will turn into an irreversible crack. $(26)^{\mathbf{2 0}}$ 


\section{Plautus and Ionesco - A Contrastive Perspective}

This disquieting feeling insinuates itself in the sphere of the ordinary. (27) The King character experiences a condition of fatigue and boredom without a clear determination. He begins to feel that he is not in his own, in himself, a kind of inner discomfort. (28) 22

Soon, queen Marguerite will announce that the King character will die. But Béringer I regards death as a remote existential event. (29) ${ }^{23}$ In the sphere of the ordinary, death appears as a well-known event. Nobody dies as long as the King character does not die. At first, he finds death unthreatening and we distinguish an apparent familiarity with death.

The disease that overtakes him can be interpreted as an anxiety. "This is because I did not set my mind to tell myself I am not ill. I did not have the time to think about this. If I think I am fine, I will recover at once."24 This incurable disease that the King experiences reminds us of Marin Sorescu's poem The Disease:

"Doctor, I feel something deadly

Here in the proximity of my own being,

All my organs ache,

During daytime my sun hurts,

And night-time the moon and the stars.

I feel a stitch in the cloud in the sky

That I haven't even noticed 'til than

And I wake up every morning

With a feeling of winter.

(...)

I think I have contracted death

One day

When I was born."25

The King begins to lose his power, nobody obeys his commands anymore. Queen Marguerite announces the King that he will be dying in an hour and a half, her words encompassing also an element of the metatheatre. (30) ${ }^{\mathbf{2 6}}$ The Doctor character realizes that the king does not have control of his own being anymore. 


\section{Monica Adriana IONESCU}

From time to time, Marguerite the queen of death informs the king how long he still has to live, rejecting the idea that what is called love can accomplish the impossible. Suddenly overtaken by fear, the King becomes nostalgic about times past. $(31)^{\mathbf{2 7}}$

The fear of death of the King character becomes more and more paralyzing: $(32)^{\mathbf{2 8}}$ The characters Marguerite and the Doctor can be considered as well personifications of destiny, of things already predetermined. (33) ${ }^{\mathbf{2 9}}$

Marguerite believes that from the perspective of the awareness of the possibility of non-existence, a different light would have been shed upon the King's life, life would have been differently valued.

Postponement represents an unauthentic way of relating one's self to death. But the permanent rumination upon death is not an authentic solution either, diminishing death's character as a possibility. (34) ${ }^{\mathbf{3 0}}$

The first sign of authentic relating to death would be the trial of recovering the exceptional character of death, from the perimeter of the Das Man. $(35)^{31}$ In the space of the impersonal self, dying has become a public event. But dying is accomplished on one's own. "Marie: Each person is for his own self the first to die." 32

Just as with Heidegger, death is treated as a social vexation in the register of the Verfallen, society making great efforts to hide disease and death. $(36)^{33}$

The duty of announcing death publicly by publication in newspapers, is affirmed. (37) $)^{\mathbf{3 4}}$

A dodging of death is presented, the dying king being told he would escape death. Deep in his heart hope is nevertheless still nestled. He would like everything that he is going through to be just a bad dream. $(38)^{\mathbf{3 5}}$

The King character would like somebody else to die instead of him, but dying by delegation is not possible, it is not possible to die instead of somebody else, death cannot be experienced by empathy. (39) ${ }^{\mathbf{3 6}}$ The Dasein cannot be replaced by anything else besides itself.

The King wants to be held back in the sphere of the Man, of the chatter, this way being able to escape death, to dodge it. $(40)^{37}$ 
Plautus and Ionesco - A Contrastive Perspective

Queen Marie proposes the king a way of saving himself from death which is efficient as long as it creates an inner feeling of eternity, and that is immersing into the amazement of being, into the miracle of existing. (41) ${ }^{\mathbf{3 8}}$ The light that the King must allow to permeate him is that of the joy of being, of existing, the light of love. (42) ${ }^{\mathbf{3 9}}$

The memory of love, the wonder of moments of times past, can defeat death because remembrance is, just like with Blaga "sole triumph of life/ over death and haze". ${ }^{40},(43)^{\mathbf{4 1}}$

The above mentioned sequence brings us to Lucian Blaga's poem Crossroads Year. The rare happening, the rare thing that prevents the two lovers (the poetic self and the loved woman) to part, is the recollection of unrepeatable moments (in the past), the wonder of love, the miracle of the moment experienced:

"Do you recall that crossroads year

So many times of parting

A time of ponder shrouded us.

Not a will of our own,

But it was demanded of us.

And each time a rare working,

A rare happening would stop us.

We used to walk the sandy beach

And footprints - sunken left behind

Would silently see the birth of the sea." 42

Queen Marie tries to revive in her beloved husband's mind the miracle of the moment past but to no avail.

The terrifying fear of death singularizes the king and he wants everybody to identify themselves with his insidious agony. But death cannot be lived through empathy, as death belongs to the individual. (44) ${ }^{\mathbf{4 3}}$

The king alienates himself from his own self, his world is foreign to him. His fear is the fear of real death, the king relating to death in an unauthentic manner. $(45)^{44}$ 


\section{Monica Adriana IONESCU}

The king truly longs for detachment, tranquillity, resignation. (46) ${ }^{\mathbf{4 5}}$ But nurturing the detached calmness alienates the Dasein even more from the state of being into death.

Anxiety opens the Dasein towards its own self. It singularizes it. (47)

The King character tries to find refuge in the sphere of the ordinary, wondering about simple things, about the miracle of being together with others. $(48)^{47}$

Within queen Maria's words one can perceive the famous Epicurean dilemma. (49) ${ }^{48}$ There is no way out of this circle. As long as we are able to reason, we do not have access to death. When death is, we are not anymore, we become simple inertial presences.

The boundless love is perceived as the supreme remedy against death because it destroys fear, love being stronger then death. (50) ${ }^{49}$ Queen Marie tries to save him from death by love. $(51)^{\mathbf{5 0}}$ Slowly, queen Marie has no more power, no more influence over the king who does not recognize her anymore, death becoming stronger than love. $(52)^{\mathbf{5 1}}$

Death means oblivion and the King forgets Marie.

Immersing into memories, he slowly submerges beyond memories, in a state of self oblivion. (53) ${ }^{\mathbf{5 2}}$

The agony of death is perceived as an immersion into himself, a slow selfdepletion, an internal paralysis which slowly becomes external. (54) ${ }^{\mathbf{5 3}}$

In the end of this play, the annihilation is complete, the nothingness is absolute.

The king has died.

In his work "Intermittent Searching", Eugen Ionescu reviews sixty-eight possible ways of dying, which is a proof of the writer's nightmares induced by the possibility of death. Our attention is captured by an example of Ophelian feminine suicide: death by drowning, the water being nocturnal. $(55)^{54}$

Gaston Bachelard believed that the contemplation of water implies dissolving oneself, dying slowly. Waters exerts an indescribable fascination upon desperate souls for which the mirage of the water when contemplated 


\section{Plautus and Ionesco - A Contrastive Perspective}

inflicts a loss of their own self. "The water dies together with the dead one in its substance. Water is then a substantial nothingness. It is not possible anymore to move forward into despair. For certain souls water is the substance of despair." (Bachelard 1995: 106)

\section{ISSUES REGARDING THE RHETORIC OF LANGUAGE IN THE IONESCIAN DRAMATURGY}

In a famous article called "Is theatre actually literature?", Caragiale states that the theatre is actually not an art genre, but an art in itself (by itself). Theatre is rather related to the art of rhetoric and to architecture. "The dramatist thus is more like an architect who designs the building, he designs it on the paper (...). The dramatist has the same reasoning - not to think of something, but to show something."1

The conclusion reached by Caragiale is a startling one: "Theatre and literature are two totally different arts, both as intention, as well as their way of manifesting themselves."

Just like the authors of "A General Rhetoric" I think that literature is, first of all, a singular use of the language and that a study of the rhetoric must take into consideration the language procedures which characterize literature. I plead for a junction "between the two tendencies, which, in a historical perspective, have torn apart the traditional rhetoric: the logical tendency, based on the conative function of the language; aesthetic tendency, reflection on the poetic function."3

Emmanuel Jacquart ${ }^{4}$ has observed three divergent tendencies characterizing the dramaturgy of the absurd: the search of abstractness, of specificity and of the undiscovered.

By searching the abstractness, the theatre of the absurd follows the abstract arts (non-figurative painting and serial music) from which it assumes certain techniques and principles.

Specificity here means theatricality (materialized structures, the importance of gestures). The language becomes, among other things, a dramatic element, its importance being drastically minimized. 


\section{Monica Adriana IONESCU}

The search of the unique event could (also) signify that the structure of a play is moulded according to the structure of the dream.

The same exegete also observes a "rhetoric of sensori(ali)zation" theatre of the absurd. In the Ionescian theatre as well, there is a configuration of the pre-eminence of the sensorial over the conceptual.

In the play "The Chairs" the idea of absence is represented by the proliferation of empty chairs. Talking about the genesis of the play, Eugen Ionescu has acknowledged that the image (of the chairs) pre-existed the idea (of absence). ${ }^{6}$ The image of the rhinoceros in the play "Rhinoceros" symbolizes any kind of ideological fanaticism, stupidity in general.

In "A General Rhetoric. The $\mu$ Group", a division of the figures of the language (metabole) is performed based on four fields: plastic, syntactic, semic, logic. The figures are divided into: metaplasms, metataxis, metasememes and metalogisms. According to the authors of "A General Rhetoric", the logical field has pure content or signified, which do not comply with any linguistic constraints or limitations.

The field of metalogisms is revealing in a discussion - analysis on the rhetoric of the Ionescian theatre (logical, chronological reversals, allegory, parable, paradox, repetition, hyperbolic silence, hyperbole, reticence, suspension, silence).

We further reproduce the overall chart of metalogisms. ${ }^{\mathbf{8}}$ 


\begin{tabular}{|c|c|}
\hline \multirow{3}{*}{$\begin{array}{l}\text { Plautus and } \\
\text { Operations }\end{array}$} & - A Contrastive Perspective \\
\hline & Metalogisms \\
\hline & On Logic \\
\hline I. Suppression & Litotes 1 \\
\hline 1. Partial & \\
\hline 2. Complete & Reticence, suspension, silence \\
\hline II. Adjunction & Hyperbole, hyperbolic silence \\
\hline 1. Simple & \\
\hline 2. Reiterative & Repetition, pleonasm, antithesis \\
\hline $\begin{array}{l}\text { III Suppression-Adjunction } \\
\text { 1. Partial }\end{array}$ & Euphemism \\
\hline 2. Complete & Allegory, parable, fable \\
\hline 3. Negative & Irony, paradox, antiphrasis, litotes 2 \\
\hline IV Permutation & Logical reversion \\
\hline 1. Random & \\
\hline 2. Through reversal & Chronological reversion \\
\hline
\end{tabular}

The play "Exit the King" has the structure of a poem. The motif of death and despair is dressed up in the folds of the hyperbole, and a hyperbolic silence sets in at the end of the play.

The realm beyond is visualized by the symbolic character the King in an allegoric way in the iridescences of an allegory kept together by the logic of the impossible. ${ }^{\mathbf{9}}(56)^{\mathbf{1 0}}$

The play "Rhinoceros" is structured as an ambiguous parable (not univocal) which cannot be defined by a meaning.

In the Ionescian theatre, silence, as a rhetoric figure, is marked either by ellipsis (suspension), or by break (as reticence). (57) ${ }^{\mathbf{1 1}}$

(The play "French Pronunciation and Conversation Exercises for American Students") are syntactically correct, but from the perspective of the meaning, they are anomalous. These statements which transgress the logical categories are called metalogisms. 


\section{Monica Adriana IONESCU}

The Ionescian theatre is abstract, non-figurative, having as a motif, not the given reality but its possibility. The artistic image is not identical to the real thing. The ideal tripolar logic of the impossible intercedes. ${ }^{\mathbf{1 2}}$

The metalogism uses as a criteria the compulsory reference to an extralinguistic given. But in the case of a statement like (58) the connection between the sign and the referee is broken. (59) ${ }^{\mathbf{1 3}}$

We further present an example of metalogic or of metalogism permutation as a chronological reversion, by extracting a sequence from the speech in

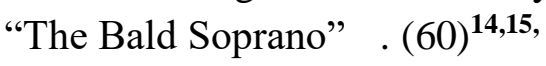

These are also anomalous statements: $(61)^{\mathbf{1 5 , 1 6 , 1 7}}$

Paradoxes (Gr. paradoxon, "contrary to expectations", "extraordinary") are metalogism versions and, according to Anton Dumitriu's definition in "The paradoxes of Logic", represent antinomies "a series of deadlocks of the thought, of contradictions which with all their evident logic, are impossible. The mind, in its necessary evolution, creates them, but it is also the mind the one which finds itself in the impossibility of accepting them."18

The oldest paradox is (considered) the one of the liar (Pseudómenos), phrased for the first time by Eubulide Megaricul: "Are you lying when you say you are lying?" two answers being possible: either "I lie" or "I do not lie."19

Paradoxes, these formal and contradictory constructions, are often encountered in the Ionescian theatre. The paradox is not just a pun; its value is measured according to the path it asserts from the language to the referee and back. $^{20}$ (62) The example above could also be interpreted as a paradoxical or anomalous syllogism. $(63)^{\mathbf{2 1}}$

This kind of paradoxes "enrich" reality, obscuring it. (64) $22,23,24$

We distinguish as well a verbal rhetoric, the Ionescian theatre being characterized by: discontinuous dialogue, ellipsis, the sentence built by parataxis, familiar construction, phonetic progression.

As far as the word is concerned, the verbal rhetoric is visible (evident) due to the presence of clichés ("Girl for Marriage"), of puns (quibbles, 


\section{Plautus and Ionesco - A Contrastive Perspective}

paronomasias, word distortions), of repetitions, accumulations or enumerations.

There is also a rhetoric of the composition. The Ionescian theatre appeals to the dream (the play "Hunger and Thirst"). The composition is based on the technique of the counterpoint (as in the play "Killing Game"), cyclic returns (as in "The Lesson"), paroxysmal acceleration (as in "The Bald Soprano"), cinematographic concatenation ("The Pedestrian of the Air"), inner monologue (in "The Chairs"), surprise effects, contrasts, opposition, polysemy sometimes pushed to paroxysm.

Like the entire dramaturgy of the absurd, the Ionescian theatre has its stake on surprise, shock, contrast, assertiveness.

\section{EUGEN IONESCU - POSTMODERN WRITER}

In his works The Postmodern Turn and The Dismemberment of Orpheus, Ihab Hassan organizes the traits of postmodernism. He proves that the classic ideal of the European culture was abandoned in the postmodern era in favour of pluralism and fragmentation, paradox, contradiction, incompleteness.

By combining the words indeterminacy and immanence, Ihab Hassan creates the term indetermanence as a defining notion for the postmodern culture.

We shall relate to the postmodern traits systematized by Ihab Hassan in order to observe to what extent Eugen Ionescu the dramatist is a postmodern writer. (Ihab Hassan: 168-173)

1. Indeterminacy. His playwrights are characterized by the indeterminacy trait, because they are open, openness being the conscious principle (with Eugen Ionescu). Eugen Ionescu is guided by the hazard principle.

2. Fragmentation. The Ionescian plays are characterized by the fragmentation trait because they have a discontinuous structure, a construction in crumbs, like the play Man with Bags. Some plays are 


\section{Monica Adriana IONESCU}

constructed from fragments which represent a concatenation of dreams.

3. Decanonization. The ideal of the present culture would be equality through difference, that is the coexistence of all cultural patterns in an interdependent pluralism.

It was already observed that Eugen Ionescu is the first writer in the Romanian literature who has tackled the ultimate play of the aesthetic canon. $^{2}$

4. Self-less-ness. The depth-less-ness would be traceable with Eugen Ionescu in his plays French Pronunciation and Conversation Exercises for American Students, The Viscount, The Niece-Wife.

5. The Unrepresentable. The Unpresentable. Many of Eugen Ionescu's plays do not have a mimetic enouncement (based on representation, on mimesis) within the limits of the verisimilar and of the necessary. The play "Rhinoceros" has a parable narration with a fantastic substance, other plays have fantastic narrations (Hunger and Thirst, The Pedestrian of the Air). Eugen Ionescu problematizes the representation, pushing it to its limits.

As well, he has a predilection for the atrocious, horrible, unpresentable, obnoxious as in his play Killing Game or Macbett.

6. Irony (or perspectivism).

In postmodernism the irony is generalized. Eugen Ionescu's plays are not tragedies, but tragic farces (tragicomedies) characterized by playfulness, by humour.

Parody is a specific trait of his plays. Eugen Ionescu's play Macbett is a parodic rewriting of the Shakespearian play, irony being the constructive principle of the text.

8. Hybridization. Postmodern art is characterized by impurity, being situated at the antipode of the classical aesthetics. Postmodern art favours the blending of styles. In the Ionescian plays, the grotesque is associated to the comic, the fantastic, the dream and the tragic, the Ionescian texts having an extraordinary formal availability. 


\section{Plautus and Ionesco - A Contrastive Perspective}

9. Carnivalization. Is manifested through a great vitality and productivity of forms. Eugen Ionescu's predilection for the mockheroic, for the burlesque is placed under the sign of the carnivalisation. If dissemination is the limitless derivation by paronomastic associations from a consonantal group not inflicted with significance, than it can be detected as well in the Ionescian plays but on small spaces of the text. $(65)^{3}$

Mesdames et messieurs qui n'existez pas, et toi public, qui es un trou noir, mon exposé contient plusieurs arguments d'importance d'où il suit que le sauveur sauvé sauvera. Tout cela c'est du foin. (...) Je vais en poser une: lève-toi, Mathieu, mets-toi des souliers bleus, des cages dans les sages, mets-toi à coudre, tes talons avec des chaussettes.

La doctrine des derniers temps tourne en rond dans les cieux, mais les égouts les rattrapent. Les égouts, ce sont des fleurs bleues et jaunes. (Ionesco, Voyages chez les morts: 133-134)

\section{Performance - Participation.}

The postmodern text is made to be manipulated by writings and rewritings, by deformations.

The plays Man with Bags and Journey Among the Dead were played together in the Ionesco montage directed by Roger Planchon in 1983.

11. Constructionism. The postmodern artist builds illusive, fictional worlds. Eugen Ionescu creates dream-like, possible, imaginary worlds in his plays, the dream becoming a means of penetrating into the sphere of the possible.

12. Immanence. The world dissolves into the language, the postmodern text refers continually to its own shape, like in the Ionescian plays where there is an abundance of metatheatre elements (double mirror play), as well as the intertextual elements.

Eugen Ionescu believed that literature is inferior to life, $(66)^{4,5}$

la littérature est en dessous de la vie, l'expression artistique est trop faible, l'imagination trop pauvre pour égaler l'atrocite et le miracle de 


\section{Monica Adriana IONESCU}

cette vie, de la mort, trop insuffisante aussi pour pouvoir en rendre compte. (Ionesco, Notes et contre-notes: 10) (...) on ne peut pas arriver à dire ce qui est indicible. Si la littérature ne peut le dire, si la mort ne peut être interprétée, si l'indicible ne peut être dit, à quoi bon, alors, la littérature ? (Ionesco, Notes et contre-notes: 373)

On one hand, the realistic, thematic, educational Plautine theatre, with a logical and rational construction; on the other hand, the anti-thematic, antiideological, anti-psychological, anti-philosophical, abstract, non-figurative Ionescian theatre. Plautus, as a genuine classic writer, is not in the search of authenticity at all costs (he is an imitator of the Greeks, drawing his inspiration on the old Greek comedies of Demophilus, Menandrus, Diphilus, Philemon, Alexis). Eugene Ionesco, obsessed by the idea of artistic originality, tries and fully manages to create new artistic forms that would enter into a relation of absolute adequacy with the perception, the condition, the feeling, the idea of absurd. Which are the elements that are common to these two authors? The "despairing" humour of Ionesco, the humour of situations and gestures, the humour of characters at Plautus. The metatheatre elements present in the works of the two dramatists. (for Plautus - the element of addressing the audience) ...

Two distinct, unmistakable, original literary universes, which centre round the human condition ...

\section{Notes}

1 Martin Esslin considers Eugen Ionescu as an avant-garde dramatist, proposing the collocation theatre of the absurd in order to describe the theatre of avant-garde authors: Beckett, Adamov, Ionesco, Genet.

2 We make a further inventory of Eugene Ionescu's other ideas about theatre: the theatre is visual and auditory, a construction, a moving architecture of scenic images; only what is unbearable is profoundly tragic, profoundly comic, is quintessential theatre. "The comic, being an intuition of the absurd, I find it more despairing than the tragic. The comic does not permit any way out. I say "despairing" but, in fact, it is beyond or hither of despair or hope." (Ibid., p.55).

3 POETIC ARTS. ROMANTICISM, Univers Publishing House, Bucharest 1982, p.302. 


\section{Plautus and Ionesco - A Contrastive Perspective}

"Romanticism, so often wrongfully defined, is, at an ultimate analyses - and the definition is true, if considered only under its militant aspect - is nothing but the liberalism in literature."

4. JACQUES DERRIDA, Positions, Editions Minuit, Paris, 1972, p. 15.

I am aware that the term deconstruction has different meanings, on artistic level the meaning of the word deconstruction not being mistaken with the meaning used in Derrida's theory. No quid pro quo is committed taking into account the array of meanings of the word deconstruction. What is more, the deconstruction of the character is not the same as giving up the character, its transformation or even its destruction.

5. Ihab Hassan, The Postmodern Turn, Ohio State University Press, 1987.

Some of the characteristics present in the chart proposed by Ihab Hassan are not specific exclusively to postmodernism. For example: irony, carnivalism, fragmentation. To be noted that these procedures cannot be used separately, on their own, as distinctive criteria. However, in postmodernism we observe a shift of the emphasis, these characteristics receiving a special importance (overwhelming). Another observation must be made as well. Postmodernism is an inclusive movement par excellence, elements of the historical avant-garde being present in postmodernism.

\section{Bibliography}

Claude Bonnefoy, Entretiens avec Eugène Ionesco, Edition Pierre Belfond, Paris, 1966

Pierre Bourdieu, Ratiuni practice . O teorie a actiunii, Meridiane Publishing House, Bucharest, 1999

Jacques Derrida, Positions, Editions Minuit, Paris, 1972

Ihab Hassan, The Postmodern Turn, Ohio State University Press, 1987

Martin Heidegger, Sein un Zeit, Max Niemeyer Verlag Tübingen, 1967

Ionesco, Théâtre, Tome I, II, III, IV, V, Paris, Gallimard, 1954, 1958, 1963

Ionesco, Voyages chez les morts, Paris, Gallimard, 1981

Stéphane Lupasco, The Dynamic Logic of Contradiction, The Political Publishing House, Bucharest, 1982

Plautus, http: //www.thelatinlibrary.com

Retorica Generala. Grupul $\mu$, Univers Publishing House, Bucharest, 1974 